\title{
Corporate Governance Mechanisms and Firm Efficiency
}

\author{
Douglas Nanka-Bruce \\ Department of Business Economics, Faculty of Economic Sciences and Business \\ Universidad Autònoma de Barcelona, 08193 Bellaterra, Barcelona, Spain \\ Tel: 34-93-581-2258Ｅ-mail: Douglas.NankaBruce@uab.es
}

Received: October 27, $2010 \quad$ Accepted: December 7, $2010 \quad$ doi:10.5539/ijbm.v6n5p28

\begin{abstract}
This paper uses technical efficiency to measure the performance impact of internal corporate governance mechanisms. Specifically, it analyzes how the size, leadership and composition of the board of directors together with external shareholders can be structured to enhance a firm's technical efficiency. The study utilizes an unbalanced pool of manufacturing firms in sixteen countries and offers support that active large external shareholders' who commit credible signals to minority investors of firms that have an insider-dominated or balanced small board with a unified leadership can lead to enhanced technical efficiency. The results also provide evidence of the convergence of American and European corporate governance practices. External shareholders are also encouraged to elect an outsider-dominated board when insiders underperform, and not on blind normative advice.
\end{abstract}

Keywords: Corporate governance, Board structure, Large shareholders, Technical efficiency, Data envelopment analysis

\section{Introduction}

Corporate governance (hereafter denoted as $C G$ ) has been defined by Denis and McConnell (2003) as a set of mechanisms that induces the self-interested managers of a company to make decisions that maximize the performance of the company to its shareholders. It deals with the limits of residual control rights of management's discretional decision making (Shleifer \& Vishny, 1997), and Jensen (1993) includes such internal mechanisms as executive compensation, internal control procedures and auditing, board of directors' responsibilities, and the structure of ownership (concentration and voting rights). Jensen also includes the market for corporate control (takeover threats), regulatory intervention, and product and factor markets in the external mechanisms.

There has been an increasing interest in determining the effect of $C G$ using a performance measure directly linked to the production process as the core of a business organization is its efficient operation of resources to achieve optimal outputs. This performance measure known as technical efficiency (hereafter denoted as $T E$ ) is the situation where, given an existing technology, a firm cannot produce a larger output from the same inputs or the same output with less of one or more inputs without increasing the amount of other inputs. Greene (1993) regards $T E$ as the relationship between an observed production and a potential production. Proponents arguing for the use of $T E$ position their argument in managerial costs of agency; where Shleifer and Vishny (1986) suggest managers sometimes undertake projects that do not add value or productivity to the firm. $T E$ can be applied to gauge this productivity loss where it could have gone unnoticed by financial ratios in the short-term (Destefanis \& Sena, 2007). Managers can also extend the useful lives of assets to delay investment in replacements which makes the production process inefficient. Applying frontier efficiency captures the evaluation of inventories and depreciation in the short term than with financial ratios (Pi \& Timme, 1993; Sheu $\&$ Yang, 2005). Another usefulness of TE is international data analysis where the equity markets across countries are different; for example the equity markets in Belgium, Greece, Italy and Spain are thin and less efficient compared to that of the United States. When using international data, $T E$ makes it possible to predict the impact of $C G$ mechanisms on performance.

This paper analyzes the conditions necessary for concentrated ownership to affect $T E$ and how the leadership, composition and size of the board can be structured to enhance $T E$. These analyses are then tested by employing a pooled international data of European and American listed firms. Any possible quadratic relationships of large shareholdings, board size or its composition on $T E$ are also considered. The results provide evidence of the 
convergence of American and European corporate governance practices; that overall $C G$ in the presence of large external shareholders can be optimized using $C E O$ duality and a small insider-dominated or balanced board. Firms are encouraged to go for outsider-dominated boards when insiders underperform and not on blind normative advice.

The rest of the paper is set out as follows: the conceptual framework considers how large shareholders, the board's size, composition and leadership can impact on TE. The methodology of estimating $T E$ is provided followed by the data sources and a description of how the variables are measured. The data analyses are carried out with double bootstrapped truncated regressions followed by a discussion of the results. The paper concludes with implications for theory and practice.

\section{Conceptual background}

A literature review of $C G$ and performance reveals that the most utilized conceptual framework of analysis is agency theory. Agency theory models managers to be individualistic, opportunistic and self-interested risk-averters motivated by their own objectives which diverge with the owners. Jensen and Meckling (1976) and Eisenhardt (1989) have chronicled that this divergence necessitates control by owners through the establishment of structures to monitor and control management. This theory predicts that governance mechanisms such as the ownership structure, and the structure and functions of the board of directors are important issues that affect performance. An alternative conceptualization is provided by the stewardship theory (Donaldson \& Davis, 1991) which models managers as collectivistic, pro-organizational and trustworthy risk-takers motivated by their owners' objectives thereby fostering structures based on trust that empower and facilitate the duty of loyalty to shareholders. It holds that performance variations arise from whether the structural situation in which the manager is located facilitates effective action by the manager (Donaldson \& Davis, 1991:51). A mutual stewardship relationship enhances performance. In this study, agency theory is used to analyze shareholding and board size while board composition and leadership are approached from the stewardship perspective.

\subsection{Large external shareholdings}

Concentrated shareholdings' is seen as a source of power that can be used to support or oppose management. Owners support management in decisions that act in their interest to maximize efficiency and oppose decisions that act to maximize management utility (Hill \& Snell, 1989). Therefore external shareholders rely on agency theory arguments for more monitoring responsibilities as concentrating shares makes it relatively easier for individual or a few shareholders to coordinate and better monitor management due to the reduction in information asymmetries (Shleifer \& Vishny, 1986 \& 1997). This is because these shareholders have enough voting power to demand accountability and influence managerial efficiency. La Porta et al. (1999: 500) however indicate that controlling shareholders may need to hold on to significant cash flow rights as a commitment to limit the expropriation of minority shareholders.

While there has been a support base for its positive effect on performance (Earle et al., 2005; Kapopoulos \& Lazaretou, 2007), other studies have reported a negative impact (Demsetz \& Villalonga, 2001), while yet other studies have reported no impact (Pedersen \& Thomsen, 1999) or non-linear associations (de Miguel et al., 2004). The contradicting findings in the agency framework requires a consideration of La Porta et al.'s (1999) assertion that controlling shareholders need to hold on to significant cash flow rights as a credible signal to minority investors for any significant positive impact on $T E$.

\section{H1: TE is positively associated with the presence of active large shareholders that hold onto significant} cash flow rights.

\subsection{Board size, composition and leadership}

La Porta et al. (1999) have documented the existence of concentrated ownership around the world even in developed capital markets. One of the key issues then, ceteris paribus, is how to structure the size, composition and leadership of the board of directors to improve performance (Erickson et al., 2005). The three board characteristics of interest are now examined.

\subsection{Size of the board of directors}

Empirical studies on board size reveal a link with performance. Goodstein et al. (1994) suggest that a bigger board is more diverse with more links to the external environment to obtain critical resources and ideas for informed choices on corporate policies that will enhance efficiency. Moreover, it is also desired when a powerful and authoritative $C E O$ is the board chairman. This paper takes the view that a larger board is required when ownership is widely dispersed or where controlling shareholders have not signaled credible commitment to minority investors and there is no other credible means to monitor management. Consequently, bigger boards 
can increase performance (Dalton et al., 1998). Bozec and Dia (2007) support this with a $T E$ measure in State-owned enterprises where monitoring by the controlling shareholder (State) is relatively weak.

Brown and Caylor (2004) however propose a maximum board size of fifteen for large firms as more free-riding increases beyond this point when some directors neglect their monitoring and resource provision duties. Agency proponents argue that even if a larger board may have diversity, firms cannot afford to increase boards ad infinitum. Particularly, in the presence of external owners with significant shares and a vested interest in monitoring management, one would expect such firms with smaller boards to have a better impact on $T E$; as the external owners, if not on the board, can take on part of the duty of managerial monitoring and leave the board to focus on scanning the environment to provide resources for management.

Consequently, a smaller board size with reduced monitoring duties will promote efficiency, strategic discussions, communication and coordination (Jensen, 1993). As the board gets bigger, there are more conflicts of interest in decision making while most board members also become passive and lazy reneging on their duties to provide resources (Jensen, 1993). Empirical support of a negative relationship between board size and performance include Eisenberg et al. (1998), and Mak and Yuanto (2002).

\section{H2: There is a negative association between TE and the size of the board of directors.}

\subsection{Board insiders}

Proponents of agency theory argue that board insiders are entrenched and negatively affect TE. They are perceived to play a less monitoring role on the board because of their self-interestedness and tunneling tendencies (Fama \& Jensen, 1983). Consequently some empirical studies find a positive relationship between the proportion of outside directors and firm performance (for example: Hossain et al., 2001; Dahya et al., 2008; Aggarwal et al., 2009). This outcome can prevail under some specific conditions such as: widely dispersed ownership; quality board outsiders with good expertise in CG issues and the industry's dynamics, and; when outside owners that can control managerial discretion would rather prefer conniving with board insiders and management to expropriate minority investors. In a situation where outside owners are in a position to monitor managerial discretion (as in concentrated ownership) and have the support of minority investors due to their credibility, the managerial monitoring duty of board outsiders (or the outside owners' representatives) becomes partially redundant; especially with board insiders having more working knowledge of the firm. This may require a reduction in the number of outsiders. In this scenario, board composition can be analyzed through stewardship theory's support of the centralization of decision making and insiders' superior knowledge of the firm's environmental terrain.

Empirical studies have also offered support for board insiders. De Jong et al. (2005) report that the Dutch supervisory board (which consists entirely of outsiders) has a negative relationship with performance. Baysinger and Hoskisson (1990) also argue that outsiders are employed on the board on a part-time basis and this limits their scope in understanding the complexities entailed in making informed decisions to improve efficiency. Tanna et al. (2008) and Lin et al. (2009) find empirical support for insider-dominated boards on TE. An insider-dominated board can increase $T E$, especially so when board insiders are argued from the stewardship theory (given their expertise) to serve firms in the interest of its owners. To forestall any self-interestedness on the part of insiders as pertaining to agency theory, a minority of quality outsiders is desired. In so far as the duties of board outsiders include monitoring board insiders on behalf of shareholders, their presence is desired but only in a minority or at best as a balanced board.

\section{H3: There is a positive association between TE and board insiders when these insiders constitute at least half the size of the board.}

\subsection{CEO duality}

A $C E O$ who is also the board chairman wields too much control that may promote entrenchment and subsequent abuse of power (Jensen, 1993). This can occur under conditions where there is no external monitoring, as occurs with an insider-dominated board with widely dispersed external ownership. Pi and Timme (1993), and Bozec and Dia (2007) have offered empirical support that under conditions such as these, a unified leadership reduces firm performance. Several empirical studies such as Finklestein and D'Aveni (1994), kang and Zardkoohi (2005), and Aggarwal et al. (2009) have argued against separating the duties of the CEO and board chairman when monitoring and other controls such as the presence of board outsiders and large external owners (with credible commitment to minority investors) are in place.

The stewardship theory argues that a unified leadership is the more desired for enhanced efficiency as a non-executive chairman has no superior knowledge of the firm's internal and environmental terrain than the 
firm's executive officers. Donaldson and Davis (1991:52) argue for CEO duality since power and authority are vested in the same individual leading to good command and control. The individual's role is "unambiguous and unchallenged [as] there is no room for doubt as to who has authority or responsibility over a particular matter".

H4: There is a positive association between TE and CEO duality.

\section{Methodology and data}

\subsection{Estimating TE through data envelopment analysis}

Performance evaluation, whether in CG or the broader field of business management, has been a critical area of research. Market value depends on investor confidence which is forward looking and profitability depends on many factors outside the direct control of firms and can be manipulated by management. There is a burgeoning literature on an alternative measure of performance in terms of TE through a nonparametric approach. Some studies have related TE with certain aspects of CG in single-country studies (and include Pi \& Timme, 1993; Nanka-Bruce, 2006; Zelenyuk \& Zheka, 2006; Bozec \& Dia, 2007; Destefanis \& Sena, 2007 and Lin et al. 2009).

$T E$ can be measured by the deviation of an observed output from its potential production frontier. The ratio of the observed to potential production is its $T E$ level. The nonparametric approach of estimating $T E$ does not use a pre-specified production function and allows one to construct a frontier based on similar inputs and outputs for a sample of firms with linear programming techniques known as Data Envelopment Analysis ( $D E A)$. As opposed to mean-variance techniques, $D E A$ uses an extreme-point method and evaluates firms in the best possible light. Research has therefore been concerned in developing techniques to reduce the influence of outliers. Regressions can then be performed using bootstrap procedures with data generating processes logically consistent with $D E A$ $T E$ estimates; making statistical inference more reliable.

Consider the mathematical program with a variable returns to scale technology (VRS) introduced by Banker et al. (1984). Let the input and output data for decision making unit $k$ be $x_{1 j}, x_{2 j} \ldots . . x_{m j}$ and $y_{I j}, y_{2 j} \ldots . . y_{j}$ respectively. The VRS DEA model (input orientation) with a real variable $\theta$ (the measure of TE) is given in EQUATION (1). The weight vector $b=\left(b_{1}, b_{2}, \ldots \ldots, b_{k}\right)$ is the activity levels of firm $k$ 's $m$ inputs and $s$ outputs. It represents the optimal (or virtual) firm $\theta^{*}$ to which firm $k$ is being compared. It does this by constructing optimal values of the more efficient firms. In the case that firm $k$ has a similar result to these other firms; it is also regarded as technically efficient and appears on the best-practice frontier:

$\theta^{*}=\operatorname{minimize} \theta$

subject to $\sum_{k=1}^{n} b_{k} x_{i k} \leq \theta x_{i}, \quad \sum_{k=1}^{n} b_{k} y_{j k} \geq y_{j k}$,

$$
b_{k} \geq 0, \quad \sum_{k=1}^{n} b_{k}=1, \quad i=\{1,2, \ldots ., m\}, \quad j=\{1,2, \ldots, s\}, k=\{1,2, \ldots \ldots, n\} .
$$

Simar and Wilson (2007) have proposed a bootstrap technique to reduce sampling errors in relative $T E$ estimations through $D E A$. This algorithm is used to compute the $T E$ score $\theta$ for each firm $k=1, \ldots, n$ by solving the linear program in EQUATION (1) as a first step. In the second step, kernel density estimation and the reflection method is used to generate a sample size $n$ from $\{\theta ; k=1, \ldots, n\}$ to provide $\left\{\theta_{1 b}^{*}, \ldots \theta_{n b}^{*}\right\}$. In the third step, a pseudo data set $\left\{\theta_{n b}^{*}\right\}$ which will form the reference bootstrap technology is computed and the pseudo data is utilized in the fourth step to compute the TE $\theta_{n b}^{*}$ of $\theta$ for each $k=1, \ldots, n$. Finally the second to fourth steps are repeated a large number of $B$ times to obtain estimates $\{\theta ; b=1, \ldots, B\}$. Confidence intervals are then constructed and maximum likelihood used for estimates of truncated regressions of $T E$ with the environmental variables.

\subsection{Data and DEA estimation of TE}

The data for this investigation is for fifteen Western European countries (namely Austria, Belgium, Denmark, Finland, France, Germany, Greece, Ireland, Italy, the Netherlands, Norway, Spain, Sweden, Switzerland, UK) and the USA for listed firms for three years (2003 to 2005). It is extracted from the Bureau van Dijk's OSIRIS 
database. The international data is necessary to test for a more global impact of the identified governance characteristics on TE. A four-digit NAICS core code is used for the data collection. This is to reduce the influence of related or unrelated strategic diversification of firms - the former which has been argued to increase $T E$ and the latter which while decreasing $T E$, is argued to decreases firm specific risk (Hill \& Snell, 1989). This industry classification implies that all firms in a sector utilize a similar production technology to convert the same input types into the same output. The five manufacturing sectors used in the DEA analysis are: Communications Equipment; Industrial Machinery; Navigational, Measuring, Medical, and Control Instruments; Pharmaceutical and Medicine, and; Semiconductor and Other Electronic Components.

The data is first refined and output is then divided by each of the three inputs to generate ratios. The formula Median $\pm 2.5 *$ Interquartile Range is applied to the resulting ratios to remove observations outside these boundaries. This procedure not only serves as detecting the presence of outliers but also makes it possible for performing regression analysis in the second stage. Cross-checking of extreme observations from the above formula is achieved with the procedure proposed by Wilson (1995) before removing influential observations from the sample. Estimating $T E$ requires a $V R S$ technology as some firms are either small or very large. An input orientation is chosen as managers have control over what to do to minimize costs associated with inputs for a constant output; as output depends on the market structure in terms of competition and customer dynamics.

The selected inputs are: the number of employees; a combination of the cost of materials and other operating expenses, and; a combination of tangible and intangible fixed assets. These industries are high-technology or knowledge intensive where intangibles are a vital input into firm survival. The choice of the number of employees indicates labor as an important factor of production. The choice of materials (material costs and other operating expenses) is because it is a vital input in the production process of manufacturers. Operating revenue is selected as the output because it is less likely to be manipulated through earnings. All variables with the exception of the number of employees are adjusted with purchasing power parity and exchange rate.

$T E$ is estimated by specifying separate technologies for all industries and years. $T E$ estimates are corrected for bias with 2000 replications and confidence intervals are estimated at $95 \%$. The total number of firms in the sample is based on those that have full data for the $T E$ estimations. It varies from 803 to 888 by yearly observations and is therefore an unbalanced pool.

\subsection{Measurement of the experimental and control variables}

Information on all variables besides board structure is from the OSIRIS database. The percentages of direct shareholdings of the first and five largest shareholders are used as a proxy for cash flow rights; as La Porta et al. (1999) assert that controlling shareholders need to signal credible commitment to limit the expropriation of minority shareholders. Information on the three board characteristics of size, composition and duality are taken from annual reports and definitive proxy statements. In this study, board independence is the proportion of non-executives with no significant shares, family or business/professional relationships with the company. For companies incorporated in countries with a two-tier board structure, no CEO duality is identified but non-executive board members with affiliations to the company are considered as insiders. In all countries, only independent non-executives are categorized as outsiders.

In order to robustly predict the relationship between $T E$ and $C G$, other important internal mechanisms that impact on efficiency have to be controlled for. Extant literature lists some of the important factors as the financial policy, firm size, growth opportunities, and learning processes. The operationalization of the measures of $T E$, shareholdings, board structure, firm size, financial policy, growth opportunities, and age are provided in TABLE 1 .

\section{(Insert TABLE 1 about here)}

The European subsample has a mean (median) share of largest owner as $34 \%(28 \%)$ and a mean (median) share of five largest owners as $61 \%(59 \%)$. The American subsample has a mean (median) share of the largest owner as $16 \%(12 \%)$ and mean (median) share of the five largest owners as $37 \%(35 \%)$. The average size of the board is seven with $62 \%$ of members as outsiders. $37 \%$ of boards have CEO duality. The size of the firms in terms of sales is much dispersed due to the fact that the sample includes small and large firms. The median five-year growth in sales is $12 \%$ while the median debt to equity ratio is 0.57 . The median age of all firms is 22.5 years. Descriptive statistics of the variables are given in TABLE 2.

\section{(Insert TABLE 2 about here)}


Correlations of the variables are generally low except board size and sales $(0.54, \mathrm{p}<0.001)$, TE and sales $(0.45$, $\mathrm{p}<0.001)$, age and sales $(0.43, \mathrm{p}<0.001)$. The highest correlation is between the percentages of the single largest shareholdings and five largest shareholdings $(0.85, \mathrm{p}<0.001)$.

\section{Results}

\subsection{Truncated regression estimations}

All the analyses are carried out with double-bootstrapped truncated regressions. The idea of using a truncated regression, rather than other types, has been argued by Simar and Wilson (2007) to be the most ideal when $T E$ is the dependent variable. The regression results $(M O D E L 1)$ in TABLE 3 excludes the experimental variables and concentrate on the associations between the variables relevant in controlling the effect of $C G$ on $T E$. The variables control for: financial leverage $(-0.02, p<0.01)$; size $(0.04, p<0.001)$; growth opportunities $(-0.05, p<$ $0.001)$; learning curve $(0.00, p<0.1)$; shareholding type, and; industry, country and year differences. The regression result shows that only individuals/families exert a significantly positive effect different from the other categories (at $0.09, p<0.05$ ). There are also significant differences in the industry and country dummies.

The Wald test statistic of the model is 369 but it is 874 when the dummies for shareholding categories are excluded, indicating the addition of age and shareholding categories weakens the basic control model. The number of observations is 495 since around half of the firms in the original sample report on the age variable. The positive association of age with $T E$ is however low $(0.00, p<0.10)$. In general, older firms are considered to be more technically efficient than newer ones because of accumulated learning experience. In order to increase the number of observations in the full specification, the age variable is dropped. The dummies for categories of the largest direct shareholder are also dropped. Prior to including all the three experimental variables into the main model, they are individually introduced with the control variables. The results support positive associations of ownership concentration, board insiders and $C E O$ duality, and a negative association of board size with $T E$. When all these variables are considered together with the control variables in the full model, the associations remain unchanged as reported in MODEL 2 (in TABLE 3).

\section{(Insert TABLE 3 about here)}

The results from MODEL 2 are now considered in detail. The Wald test statistic of MODEL 2 (933) reveals the significant contributions of the main effects in the main model. A unit increase in cash flow ownership leads to a 0.1 increase in $T E(p<0.01)$ supporting hypothesis $H 1$ that large shareholdings enhance $T E$; as large shareholders signal commitment to minority investors by holding on to significant cash flow rights. A unit increase in board size leads to a 0.01 deficit in $T E(p<0.001)$ supporting hypothesis $H 2$ that smaller boards increase TE. A unit increase in board insiders' results in an increase of $0.1(p<0.001)$ on TE. Hypothesis H3 which predicts a positive association of board insiders and $T E$ is supported. The last governance variable of interest (H4) is the positive effect of $C E O$ duality on $T E$. The regression result supports a positive relationship of $C E O$ duality $(0.03, p<0.001)$.

The $T E-C G$ relationship has been controlled with some firm specific, industry, country and year parameters. The elasticity effect of firm size $(\log S A L E S)$ is positive $(0.05, p<0.001)$ and relates to the increasing effects of scale economies on TE (Lin et. al., 2009). Financial policy $(-0.03, p<0.01)$ relates that more efficient firms may choose higher equity and lower debts to protect the profits generated by higher efficiency from the likelihood of liquidation (Kapopoulos \& Lazaretou, 2007). Growth opportunities (average of five-year SALES GROWTH) is negatively associated with $T E(-0.03, p<0.01)$. The idea of $T E$ (from an input orientation perspective) is to minimize agency costs involved in decision making of a desired output from a set of inputs. If the market for the output has growth potential, firms are not under survival threat for more efficient production processes and are likely to be less efficient than firms with low growth potential.

\subsection{Further tests}

In order to check the reliability of the models' significance of the predicted relationships, some further tests are carried out. Regressions are carried out interacting country dummies with the experimental and control variables. The results indicate no significant interactions. The sample is also divided into firms incorporated in the USA (MODEL 3) and Europe (MODEL 4) to test for similarities or differences in the impact of the $C G$ variables on $T E$. The results are presented in TABLE 3 and TABLE 4 respectively. Although the experimental and control variables' coefficients vary slightly between these two subsamples and the full sample (MODEL 2), all the established relationships are significant and persist across the subsamples, except $C E O$ duality in the European sample; where although it has an increased association with $T E$ (by 0.02 units) than a $C E O$ separation, this difference is not significant at conventional levels. 


\section{(Insert TABLE 4 about here)}

The next test is addition of age (proxy for learning curve; $0.00, p<0.05$ ) and the categories of largest shareholdings to the full model specified in MODEL 2. The results are given in MODEL 5 in TABLE 4. Large shareholdings' is indexed as the five largest shareholdings in place of the cash flow shares of the single largest shareholdings. The results in MODEL 5 support all the predictions from MODEL 2, even though the observations $(n=164)$ excludes firms from Greece, Italy, Norway and Spain and is a subsample of MODEL $2(n$ $=1140$ ). It also confirms the finding in $M O D E L 1$ that only the Individuals/Families shareholding category exerts a systematic positive effect on $T E(0.15, p<0.1)$.

There has been evidence of non-linear associations of performance with large shareholdings (de Miguel et al., 2004), board size (Brown \& Caylor, 2004) and board composition (Dwivedi \& Jain, 2004). This paper analyzes these assertions by adding the squares of large shareholdings, board size and board insiders, individually and collectively, to the experimental and control variables in MODEL 2. The quadratic specification of board insiders is particularly important as the third hypothesis development - $H 3$ allows for the inclusion of fewer quality board outsiders or a balanced board for improved TE.

The results when the three governance variables are collectively introduced with their second order polynomials are presented in MODEL 6 of TABLE 4. The coefficient of the largest shareholder becomes insignificant $(0.19$, $p>0.1)$ while the coefficient on its second order is negative but insignificant $(-0.14, p>0.1)$ ruling out a significant quadratic relationship. The coefficient of board insiders is positive $(0.15, p<0.1)$ and the coefficient on its second order is negative $(-0.22, p<0.01)$ implying a concave relationship with $T E$ which support insider-dominated and balanced boards. This means that while the inclusion of outsiders has a positive association on $T E$, as the proportion is increased and outsiders dominate, it leads to a negative effect on $T E$.

With board size there is evidence of an insignificant convex relationship; as the coefficient of board size is negative $(-0.04, p<0.001)$ and the coefficient of its second order is insignificantly positive (at $0.00, p>0.1$ ). The sample is consequently divided into three groups based on Brown and Caylor's (2004) assertion that a board size of between six and fifteen members is ideal. The average size of the board in the sample is seven with a maximum of twenty members. Out of the 1140 observations in MODEL 2, only five observations have more than fifteen members. As a result of this, a regression without the industry and country dummies in MODEL 2 is run on the group comprising larger boards $(13-20$ members $)$ with 26 observations $(-0.03, p<0.05)$. For the ideal group (6-12 members), there are 943 observations and MODEL 2 is run (with a result of $-0.02, p<0.001$ ). There are 171 observations forming the third group of smaller boards (1-6 members) and the model is run (with a result of $-0.06, p<0.01$ ). The three results all point to a negative relationship between $T E$ and board size.

\section{Discussion}

Large shareholders have been argued to have the ability to expropriate minority investors (La Porta et al., 1999). To limit the effect of expropriation, a measure of the cash flow rights of the largest and five largest shareholders has been used as a sign of credibility towards minority investors. The result supports a positive impact on $T E$. This relationship holds even when the sample is split into European and American firms; the USA is characterized by less concentrated ownership as already reported in this study. Earle et al. (2005) and Kapopoulos and Lazaretou (2007) have offered support for the positive effect of concentrated ownership on performance.

The results have not supported the non-linear relationship argument of ownership that has been reported in some studies as only cash flow ownership has been considered. Demsetz and Lehn (1985) have established that different ownership categories may have different objectives, monitoring skills and incentives. Individuals/families are the most involved because of the risks involved with their sunk costs (Pedersen \& Thomsen, 1999). This is reflected in this study, as it is the only category whose positive association with $T E$ is significantly different from the other categories. Financial firms have the required resources and monitoring skills but are more likely (from the agency perspective) to align with managerial interest as they have more dispersed holdings across diversified portfolios.

Having established the influence of large shareholdings, the relationship of the board characteristics with $T E$ is considered. The negative association of performance and board size (Eisenberg et al., 1998; Mak \& Yuanto, 2002) that has been argued from the agency perspective is supported with the $T E$ measure. The sample's mean and median board size of seven is within the ideal requirement (Brown \& Caylor, 2004). A smaller board size increases $T E$ because conflicts involved in atomistic decision making are reduced; as large external owners with significant cash flow rights take on part of the managerial monitoring duties, leaving the board to focus on scanning the environment for resources that enhance efficiency. 
The composition of the board has revealed that board insiders are desired for improved $T E$ (see also Tanna et al., 2008; Lin et al., 2009) but there is also evidence of a concave association proposed elsewhere by Dwivedi and Jain (2004). This leads to the suggestion that board outsiders are required to monitor management and executive board members and also add quality expertise. But when their numbers dominate the board, it can lead to reductions in board effectiveness (which is reflected in a decrease in $T E$ ). This is especially so in the presence of active outside owners with significant cash flow rights. The current requirement of an independent board in countries with no legal requirement (reflected in $C G$ codes and indices) can be detrimental to $T E$ as outsiders have less informational access for efficient decision making. The decisions of these non-executives may conflict with that of executives, reducing managerial motivation (Donaldson \& Davis, 1991). There is a trade-off that firms should make as to the importance of $T E$ versus market value; as governance codes currently prescribe an outsider-dominated board; that investors have perceived as a credible signal. The practice of firms with active large shareholders that have insider-dominated or balanced boards is also desired for improved TE.

The study has revealed a marginal positive difference between the effects of $C E O$ duality versus separation on $T E$. The positive correlation on $T E$ is however not robust in the European subsample. Daily and Dalton (1997) make a case of "much ado about nothing" in the CEO-board chairman unified or dual leadership roles. The conventional performance measures have not being able to prescribe any relevant significance of board leadership, but $C G$ codes and indices continue to prescribe the separation of the duties of the $C E O$ and board chairman. This investigation has revealed that this agency theoretical prescription can be detrimental to $T E$ as the stewardship perspective of duality proposed by Donaldson and Davis is partially supported. CEO duality should not be discouraged by firms in countries where it is not mandatory because of normative considerations but with an in-depth analysis of all other corporate governance mechanisms.

\section{Conclusion}

Firms in all countries have been analyzed together and subsequently split into European and American samples to confirm the established relationships. Proponents of the convergence hypothesis argue that a good number of large listed firms are cross-listed on several international stock exchanges and therefore it is in the interest of firms to embrace similar governance codes; as seen in the development of $C G$ indices used by rating agencies to rate firms across borders. The result of this study largely supports the convergence argument of European and American governance practices. The study has a disproportionate number of publicly-listed American manufacturing firms in the sample due to the country's bigger equity market. It is therefore necessary in the future to involve a larger representative matched sample including privately-listed firms over a longer period across the larger industrial economy.

Previous research into $C G$ and $T E$ has focused on $T E$ as a performance measure in single country contexts but it is also useful in cross-country analysis. The impact of internal $C G$ characteristics on performance across countries can be efficiently addressed from a $T E$ perspective; as valuation is sensitive to differences in the efficiency of equity markets, and financial ratios are sensitive to different accounting techniques and manipulation of earnings. The myopic behavior of management can also be captured in the use of TE. Improving $T E$ limits managerial discretion for value-decreasing activities. Outside influential shareholders and non-executive board members can encourage the comparison of their firms' inefficiencies with industry peers to use as one of the justifications when disciplining management for poor performance.

This investigation has analyzed the impact of large external owners with significant cash flow rights on $T E$. It has also considered how the board's size, composition and leadership can be structured for a positive effect on $T E$. $C G$ can contribute to a better $T E$ by increasing the shares of large external shareholders who have signaled credibly against expropriation of minority investors, and using small insider-dominated or balanced boards with unified leadership. Large shareholders and properly composed small boards have the potential to reduce the choice set available to managers to pursue strategies and policies that are detrimental to $T E$. It is suggested that firms should increase outsiders on the board when insiders underperform or where ownership is widely dispersed, and not on blind normative advice.

\section{References}

Aggarwal, R., Erel, I., Stulz, R., \& Williamson, R. (2009). Differences in governance practices between U.S. and foreign firms: measurement, causes, and consequences. Review of Financial Studies, 22, 3131 - 3169.

Banker, R.D., Charnes, A., \& Cooper, W.W. (1984). Some models for estimating technical and scale inefficiencies in data envelopment analysis. Management Science, 30, 1078-1092. 
Baysinger, B.D., \& Hoskisson, R.R. (1990). The composition of boards of directors and strategic control: effects on corporate strategy. Academy of Management Review, 15, 72-87.

Bøhren, Ø., \& Ødegaard, B. A. (2006). Governance and performance revisited, in Ali, P. \& Gregouriu, G. (eds.), International corporate governance after Sarbanes-Oxley, Hoboken NJ, Wiley, 27-64.

Bozec, R., \& Dia, M. (2007). Board structure and firm technical efficiency: evidence from Canadian state-owned enterprises. European Journal of Operational Research, 177, 1734-1750.

Brown, L.D., \& Caylor, M.L. (2004). Corporate governance and firm performance, Working paper, Georgia State University.

Dahya, J., Orlin, D., \& McConnell, J.J. (2008). Dominant shareholders, corporate boards and corporate value: a cross-country analysis. Journal of Financial Economics, 87, 73-100.

Daily, C.M., \& Dalton, D.R. (1997). CEO and board chair roles held jointly or separately: much ado about nothing? Academy of Management Review, 11, 11-20.

Dalton, D.R., Daily, C.M., Ellstrand, A.E., \& Johnson, J.L. (1998). Meta-analytic review of board composition, leadership structure, and financial performance. Strategic Management Journal, 19, 269-290.

De Jong, A., DeJong, D.V., Mertens, G., \& Wasley, C.E. (2005). The role of self-regulation in corporate governance: evidence and implications from the Netherlands. Journal of Corporate Finance, 11, 473-503.

De Miguel, A., Pindado, J., \& de la Torre, C. (2004). Ownership structure and firm value: new evidence from Spain. Strategic Management Journal, 25, 1199-1207.

Demsetz, H., \& Lehn, K. (1985). The structure of corporate ownership: causes and consequences. Journal of Political Economy, 93, 1155-1177.

Demsetz, H., \& Villalonga, B. (2001). Ownership structure and corporate performance. Journal of Corporate Finance, 7, 209-233.

Denis, D.K., \& McConnell, J.J. (2003). International corporate governance. Journal of Financial and Quantitative Analysis, 38, 1-36.

Destefanis, S., \& Sena, V. (2007). Patterns of corporate governance and technical efficiency in Italian manufacturing. Managerial and Decision Economics 28, 27-40.

Donaldson, L., \& Davis, J.H. (1991). Stewardship theory or agency theory: CEO governance and shareholder returns. Australian Journal of Management, 16, 49-64.

Dwivedi, N., \& Jain, A.K. (2004). Board effectiveness and corporate performance: a holistic view and research agenda, paper published in the proceedings of the 25th McMaster world congress on enhancing corporate governance, Hamilton, Ontario - Canada.

Earle, J.S., Kucsera, C., \& Telegdy, A. (2005). Ownership concentration and corporate performance on the Budapest stock exchange: do too many cooks spoil the goulash? Corporate Governance: An International Review, 13, 254-264.

Eisenberg, T., Sundgren, S., \& Wells, M.T. (1998). Larger board size and decreasing value in small firms. Journal of Financial Economics, 48, 35-54.

Eisenhardt, K.M. (1989). Agency theory: an assessment and review. Academy of Management Review, 14, $57-74$.

Erickson, J., Park, Y.W., Reising, J., \& Shin, H.H. (2005). Board composition and firm value under concentrated ownership: the Canadian evidence. Pacific-Basin Finance Journal 13, 387-410.

Fama, E.F., \& Jensen, M.C. (1983). Separation of ownership and control. Journal of Law and Economics, 26, 301-349.

Finkelstein, S., \& D'Aveni, R.A. (1994). CEO duality is double-edged sword: How boards of directors balance entrenchment avoidance and unity command. Academy of Management Journal, 37, 1079-1108.

Goldstein, J., Gautam, K., \& Boecker, W. (1994). The effects of board size and diversity on strategic change. Strategic Management Journal, 15, 241-250.

Greene, W.H. (1993). Frontier Production Functions, Stern School of Business working paper EC-93-20, New York University. 
Hill, C.W.L., \& Snell, S.A. (1989). Effects of ownership structure and control on corporate productivity. Academy of Management Journal, 32, 25-46.

Hossain, M., Prevost, A., \& Rao, R. (2001). Corporate governance in New Zealand: the effect of the 1993 companies act on the relation between board composition and firm performance. Pacific Basin Finance Journal, 9, 119-145.

Jensen, M. (1993). The modern industrial revolution, exit, and the failure of internal control systems. Journal of Finance, 48, 831-880.

Kang, E., \& Zardkoohi, A. (2005). Board leadership structure and firm performance. Corporate Governance: An International Review, 13, 785-799.

Kapopoulos, P., \& Lazaretou, S. (2007). Corporate ownership structure and performance: evidence from Greek firms. Corporate Governance: An International Review, 15, 144-158.

La Porta, R., Lopez-de-Silanes, F., \& Shleifer , A. (1999). Corporate ownership around the world. Journal of Finance, 54, 471-517.

Lin, C., Ma, Y., \& Su, D. (2009). Corporate governance and firm efficiency: evidence from China's publicly listed firms. Managerial and Decision Economics, 30, 193-209.

Mak, Y.T., \& Yuanto, K. (2002). Size really matters: further evidence on the negative relationship between board size and firm value. National University of Singapore (NUS) business school working paper.

Nanka-Bruce, D. (2006). Corporate ownership and technical efficiency analysis in the Spanish real estate sector. Corporate Ownership \& Control, 4, 100-113.

Pedersen, T., \& Thomsen, S. (1999). Economic and systemic explanations of ownership concentration among European's largest companies. International Journal of the Economics of Business, 6, 367-381.

Pi, L., \& Timme, S. (1993). Corporate control and bank efficiency. Journal of Banking \& Finance, 17, 515-530.

Sheu, H.J., \& Yang, C.H. (2005). Insider ownership and firm performance in Taiwan's electronics industry: a technical efficiency perspective. Managerial and Decision Economics, 26, 307-318.

Shleifer, A., \& Vishny, R.W. (1986). Large shareholders and corporate control. Journal of Political Economy, 94, 461-488.

Shleifer, A., \& Vishny, R.W. (1997). A survey of corporate governance. Journal of Finance, 52, 737-783.

Simar, L., \& Wilson, P.W. (2007). Estimation and inference in two-stage, semi-parametric models of production processes. Journal of Econometrics, 136, 31-64.

Wilson, P.W. (1995). Detecting influential observations in data envelopment analysis. Journal of Productivity Analysis, 6, 27-46.

Zelenyuk, V., \& Zheka, V. (2006). Corporate governance and firms' efficiency: the case of a transitional country, Ukraine. Journal of Productivity Analysis, 25, 143-157. 
Table 1. Variables and measures

\begin{tabular}{|c|c|c|}
\hline Variable & Measure & Operationalization \\
\hline Age & $\begin{array}{l}\text { Learning } \\
\text { curve }\end{array}$ & The number of years since a firm's incorporation. \\
\hline $\begin{array}{l}\text { Bias-corrected } \\
\text { Technical } \\
\text { Efficiency }(T E)\end{array}$ & Performance & $\begin{array}{l}\text { Inputs: Cost of materials }+ \text { other expenses, Number of employees, } \\
\text { Tangible fixed assets }+ \text { Intangible fixed assets. Output: Operating } \\
\text { revenue (turnover). Monetary values are corrected with purchasing } \\
\text { power parity and exchange rate. }\end{array}$ \\
\hline Board insiders & $\begin{array}{l}\text { Corporate } \\
\text { control }\end{array}$ & $\begin{array}{l}\text { The ratio of executive or affiliated directors to the size of the board. This } \\
\text { is taken from annual reports and definitive proxy statements. }\end{array}$ \\
\hline Board size & $\begin{array}{l}\text { Corporate } \\
\text { control }\end{array}$ & $\begin{array}{l}\text { The number of directors of the company's board. This is taken from } \\
\text { annual reports. }\end{array}$ \\
\hline$C E O$ duality & $\begin{array}{l}\text { Corporate } \\
\text { control }\end{array}$ & $\begin{array}{l}\text { The } C E O \text { is the chairman of the board. This is measured as a dummy } \\
\text { variable. This is taken from annual reports. }\end{array}$ \\
\hline Leverage & $\begin{array}{l}\text { Financial } \\
\text { policy }\end{array}$ & Total debt to total assets. \\
\hline $\begin{array}{l}\text { Large } \\
\text { shareholdings }\end{array}$ & $\begin{array}{l}\text { Corporate } \\
\text { control }\end{array}$ & $\begin{array}{l}\text { Ratio of largest direct shares or five largest direct shares representing } \\
\text { cash flow ownership which is a credible signal to minority investors. } \\
\text { This is taken from OSIRIS }\end{array}$ \\
\hline Ownership identity & $\begin{array}{l}\text { Corporate } \\
\text { control }\end{array}$ & $\begin{array}{l}\text { The identity of the largest shareholder. These are: Individuals/Families; } \\
\text { Financial Companies; Public Companies; Industrial Companies; State, } \\
\text { and; Other Unnamed Shareholding Aggregates, Foundations and } \\
\text { Research Institutions or Private Investor. This is operationalized as } \\
\text { dummy variables. }\end{array}$ \\
\hline Sales & Firm size & Natural logarithm of total sales in thousand of USA dollars. \\
\hline Sales growth & $\begin{array}{l}\text { Growth } \\
\text { opportunities }\end{array}$ & \\
\hline
\end{tabular}

Table 2. Descriptive statistics of variables used in estimations

\begin{tabular}{|lccccc|}
\hline Variable & Mean & Median & Standard deviation & Minimum & Maximum \\
\hline Technical Efficiency $(T E)$ & 0.67 & 0.71 & 0.19 & 0.10 & 0.98 \\
\hline Board size & 7.20 & 7 & 2.50 & 1 & 20 \\
\hline Largest shares & 0.23 & 0.15 & 0.19 & 0.01 & 0.84 \\
\hline Board insiders & 0.38 & 0.33 & 0.22 & 0 & 1 \\
\hline Leverage & 0.77 & 0.57 & 0.80 & -2.29 & 3.54 \\
\hline Sales & 1082000 & 95000 & 4267000 & 100 & 50500000 \\
\hline 5-year sales growth & 0.25 & 0.12 & 0.55 & -0.53 & 7.53 \\
\hline Age & 39.70 & 22.50 & 41.40 & 4 & 233 \\
\hline
\end{tabular}

The sales variable is measured in thousands of USA dollars. Maximum number of included observations in the three-year pool for the descriptive statistics is 2541 which is for the $T E$ variable. The number of observations for largest shareholder is 1867 , board size is 2492, board composition (both insiders and outsiders) is 1996, board leadership is 2515 (this statistic is not included in the table as it is operationalized as a binary variable with $37.3 \%$ being $C E O$ duality type), leverage is 2321 , sales is 2532 , sales growth is 2055 , and age is 802 . 
Table 3. Control variables models and full model

\begin{tabular}{|c|c|c|c|}
\hline Variables & MODEL 1: Controls & MODEL 2: Full model & MODEL 3: USA \\
\hline Technical Efficiency $(T E)$ & $\begin{array}{c}\text { Coefficient } \\
\left.\text { (standard error }{ }^{\$}\right)\end{array}$ & $\begin{array}{c}\text { Coefficient } \\
\left.\text { (standard error }{ }^{\$}\right)\end{array}$ & $\begin{array}{c}\text { Coefficient } \\
\left.\text { (standard error }{ }^{\$}\right)\end{array}$ \\
\hline \multicolumn{4}{|c|}{ Corporate Governance (CG) parameters } \\
\hline Largest shareholdings & & $0.11 * *(0.04)$ & $0.10^{\dagger}(0.05)$ \\
\hline Board size & & $-0.01 * * *(0.00)$ & $-0.02 * * *(0.0)$ \\
\hline Board insiders & & $0.11 * * *(0.03)$ & $0.09 * *(0.04)$ \\
\hline$C E O$ duality & & $0.03 * * *(0.01)$ & $0.03 * *(0.01)$ \\
\hline \multicolumn{4}{|c|}{ Control for firm heterogeneity } \\
\hline Leverage & $-0.02 * * *(0.01)$ & $-0.03 * * *(0.01)$ & $-0.02 *(0.01)$ \\
\hline Log Sales & $0.04 * * *(0.00)$ & $0.05 * * *(0.00)$ & $0.05 * * *(0.00)$ \\
\hline Sales growth & $-0.05 * * *(0.01)$ & $-0.03 * *(0.01)$ & $-0.02^{\dagger}(0.01)$ \\
\hline Age & $0.00^{\dagger}(0.00)$ & & \\
\hline \multicolumn{4}{|c|}{ Year dummies, constant, tests and statistics } \\
\hline Year 2003 & $-0.01(0.01)$ & $0.01(0.01)$ & $0.00(0.01)$ \\
\hline Year 2004 & $-0.04 * * *(0.01)$ & $0.02^{\dagger}(0.01)$ & $0.02(0.01)$ \\
\hline Constant & $0.30 * * *(0.08)$ & $0.09^{\dagger}(0.05)$ & $0.37 * * *(0.05)$ \\
\hline /sigma & $0.11 * * *(0.00)$ & $0.14 * * *(0.00)$ & $0.15 * * *(0.00)$ \\
\hline$A I C / B I C$ & $-835 /-701$ & $-1540 /-1389$ & $-1069 /-997$ \\
\hline $\mathrm{N}^{\mathrm{o}}$. of observations & 495 & 1140 & 863 \\
\hline Wald $\mathrm{chi}^{2}$ & $369^{* * *}[30]$ & $933 * * *[28]$ & $260 * * * \quad[13]$ \\
\hline Log likelihood & 450 & 800 & 549 \\
\hline
\end{tabular}

$* * *|* *| *|\dagger=p<0.1 \%|<1 \%|<5 \%|<10 \% . \$=$ bootstrap standard errors of observed coefficient in parentheses are achieved with 500 replications. $[\cdot]=$ degrees of freedom. MODEL 1 includes all the control variables including shareholding categories, industry and country controls. MODEL 2 is the main model being tested with all predicting governance parameters and control variables excluding age and shareholding categories. It is formulated below as:

$$
\begin{aligned}
T E_{i t} & =\alpha+\beta_{1} L A R G E_{-} S H A R E H O L D I N G S_{i t}+\beta_{2} B O A R D_{-} S_{I Z E_{i t}}+\beta_{3} \text { BOARD_INSIDERS }_{i t}+\beta_{4} C E O O_{-} D U A L I T Y_{i t} \\
& +\beta_{5} L O G_{-} S A L E S_{i t}+\beta_{6} \text { SALES_GROWTH }_{i t}+\beta_{7} L E V E R A G E_{i t}+\sum_{j=8}^{j=12} \beta_{j} I N D U S T R Y_{j i i}+\sum_{k=13}^{k=28} \beta_{k} C O U N T R Y_{k i t}+\sigma \lambda_{i t}+\varepsilon_{i t}
\end{aligned}
$$

$\alpha$ is the common intercept of the model; $\lambda$ is the inverse Mills ratio; $\sigma$ is a coefficient introduced for the limited dependent variable $T E ; i$ is the observation at period $t ; \varepsilon$ is the random error term for statistical noise, and; $\beta_{1}$ through $\beta_{k}$ are unstandardized coefficients denoting marginal effects of the parameters on TE. MODEL 3 uses only data on US firms with all variables (excluding country dummies) from the main model. 
Table 4. Robust specifications by subsamples

\begin{tabular}{|c|c|c|c|}
\hline Variables & $\begin{array}{c}\text { MODEL } 4 \\
\text { Europe }\end{array}$ & $\begin{array}{c}\text { MODEL } 5 \\
\text { All predicting variables }\end{array}$ & $\begin{array}{c}\text { MODEL 6 } \\
\text { Quadratic relationships }\end{array}$ \\
\hline Technical Efficiency $(T E)$ & $\begin{array}{c}\text { Coefficient } \\
\left.\text { (standard error }{ }^{\$}\right)\end{array}$ & $\begin{array}{c}\text { Coefficient } \\
\left(\text { standard error }^{\$}\right)\end{array}$ & $\begin{array}{c}\text { Coefficient } \\
\left.\text { (standard error }{ }^{\$}\right)\end{array}$ \\
\hline \multicolumn{4}{|c|}{ Corporate Governance (CG) parameters } \\
\hline Largest shareholdings & $0.10 * *(0.04)$ & & $0.19(0.12)$ \\
\hline Squared largest shareholdings & & & $-0.14(0.17)$ \\
\hline Five largest shareholdings & & $0.13 *(0.06)$ & \\
\hline Board size & $-0.01 * *(0.00)$ & $-0.01 * * *(0.00)$ & $-0.04 * * *(0.01)$ \\
\hline Squared board size & & & $0.00(0.01)$ \\
\hline Board insiders & $0.10 * * 0.04)$ & $0.10^{\dagger}(0.05)$ & $0.15^{\dagger}(0.09)$ \\
\hline Squared board insiders & & & $-0.22 * *(0.08)$ \\
\hline$C E O$ duality & $0.02(0.02)$ & $0.04^{\dagger}(0.03)$ & $0.03 * * *(0.01)$ \\
\hline \multicolumn{4}{|c|}{ Control for category of ownership and firm heterogeneity } \\
\hline Leverage & $-0.04 * * *(0.01)$ & $-0.05 * * *(0.01)$ & $-0.03 * * *(0.01)$ \\
\hline Log Sales & $0.05^{* * *}(0.01)$ & $0.06 * * *(0.01)$ & $0.05 * * *(0.00)$ \\
\hline Sales growth & $-0.04^{\dagger}(0.02)$ & $-0.04 * *(0.01)$ & $-0.03 * *(0.01)$ \\
\hline Age & & $0.00 *(0.00)$ & \\
\hline \multicolumn{4}{|c|}{ Year dummies, constant, tests and statistics } \\
\hline Year 2003 & $0.04 * *(0.02)$ & $-0.02(0.02$ & $0.01(0.01)$ \\
\hline Year 2004 & $0.03^{\dagger}(0.02)$ & $-0.06 * *(0.02)$ & $-0.01(0.01)$ \\
\hline Constant & $0.00(0.08)$ & $-0.20(0.15)$ & $0.14 *(0.07)$ \\
\hline Sigma & $0.10 * * *(0.01)$ & $0.10 * * *(0.01)$ & $0.14 * * *(0.00)$ \\
\hline$A I C / B I C$ & $-493 /-388$ & $-275 /-179$ & $-1546 /-1380$ \\
\hline $\mathrm{N}^{\mathrm{o}}$. of observations & 277 & 164 & 1140 \\
\hline Wald chi ${ }^{2}$ & $827 * * *[27]$ & $204 * * *[29]$ & $924 * * *[31]$ \\
\hline Log likelihood & 276 & 169 & 806 \\
\hline
\end{tabular}

$* * *|* *| *|\dagger=p<0.1 \%|<1 \%|<5 \%|<10 \% . \$=$ bootstrap standard errors of observed coefficient in parentheses are achieved with 500 replications. [·]= degrees of freedom. MODEL 4 analyzes firms from fifteen Western European countries. MODEL 5 makes a more robust test of the analysis using all the control variables prescribed from theory (in the base control model) and the $C G$ parameters under investigation. MODEL 6 tests for quadratic relationships in largest shareholdings, board size and board insiders in the full model (MODEL 2). 